A R C HIWA, BIBLIOTEKI

I MUZEA KOŚCIELNE 103 (2015)

\author{
MAŁGORZATA DUDZIAK-KOWALSKA* - KRAKÓW \\ BARBARA JANCZAK** - KRAKÓW
}

\title{
BIBLIOTEKA OPACTWA ŚW. WOJCIECHA MNISZEK BENEDYKTYNEK W STANIĄTKACH
}

\section{Wstęp}

Tylko nieliczne klasztory w Polsce mogą poszczycić się tak długą i nieprzerwaną działalnością jak opactwo sióstr benedyktynek z podkrakowskich Staniątek. Założone zostało bowiem około 1250 roku, a jego fundatorem był kasztelan krakowski Klemens Jaksa herbu Gryf z Ruszczy i jego żona Racława ${ }^{1}$. Ich córka Wisenna została pierwszą ksienią klasztoru. Bogata historia klauzurowego zakonu od dawna była przedmiotem zainteresowania badaczy. W licznych pracach dotyczących głównie historii konwentu, wielokrotnie wzmiankowano też o klasztornej bibliotece, jednak jak dotąd nie ukazała się powszechnie dostępna publikacja na temat jej dziejów, rozwoju zbiorów oraz aktualnej działalności². Warto zauważyć, że w literaturze przedmiotu w ogóle zagadnienie bibliotek żeń-

* Małgorzata Dudziak-Kowalska - mgr bibliotekoznawstwa i informacji naukowej, starszy kustosz dyplomowany, kierownik Oddziału Opracowania Zbiorów Biblioteki Głównej AGH w Krakowie, e-mail: malgorzata.kowalska@bg.agh.edu.pl

** Barbara Janczak - mgr bibliotekoznawstwa i informacji naukowej, starszy kustosz dyplomowany w Bibliotece Głównej AGH w Krakowie, e-mail: janczak@bg.agh.edu.pl

${ }^{1} \mathrm{~J}$. Marecki, Zakony żeńskie w Polsce i instytuty życia konsekrowanego, instytuty i zgromadzenia zakonne, instytuty świeckie, wspólnoty życia apostolskiego, Kraków 1997, s. 11. J. Marecki jako datę postania opactwa przyjmuje rok ok. 1250. Istnieją niekiedy rozbieżności odnośnie do daty powstania opactwa. Według tradycji, klasztor został ufundowany w roku 1228, a w $1238 \mathrm{r}$. konsekracji świątyni dokonał biskup krakowski Wisław. Podstawowymi dokumentami dla opactwa są jednak bulle protekcyjne papieża Innocentego IV z lat 1252 i 1253 zatwierdzające fundację staniątecką oraz przywilej księcia Bolesława Wstydliwego z roku 1254 potwierdzający nadania ziemskie dla opactwa, zob. m.in.: M. Borkowska, Stownik mniszek benedyktyńskich w Polsce, Tyniec 1989, s. 6, 105; M. Pielesz, Opactwo Benedyktynek w Staniątkach. Przewodnik. Kraków 2011, s. 23-25; W. Kolak, J. Marecki, S. Radoń, Inwentarz Archiwum Benedyktynek w Staniątkach, Kraków 2003, s. IX.

${ }^{2}$ Obszerną historię biblioteki przedstawiła Beata Wojewoda w obronionej w 1990 r. w Uniwersytecie Śląskim pracy magisterskiej pt. Biblioteka Klasztoru Panien Benedyktynek w Staniątkach. Maszynopis pracy przechowywany jest w Archiwum Benedyktynek w Staniątkach (dalej: ABS) 
skich zakonów w Polsce przewija się marginalnie, dotyczy to również piśmiennictwa na temat księgozbiorów benedyktynek ${ }^{3}$.

Losy księgozbioru sióstr benedyktynek w Staniątkach są ściśle powiązane z dziejami samego konwentu. Założona w 1762 roku biblioteka klasztorna zachowała się do czasów współczesnych m.in. dzięki temu, że w klasztorze prowadzono szkołę dla panien ${ }^{4}$. Z tego powodu zgromadzenie jako jedno z niewielu w zaborze austriackim, pomimo wrogiego nastawienia ówczesnego ustawodawstwa do życia kontemplacyjnego, nie uległo kasacji ${ }^{5}$. Siostry benedyktynki będąc niejednokrotnie na przestrzeni lat świadkami i uczestniczkami dramatycznych wydarzeń (wojny, zniszczenia, wypędzenia), zawsze potrafiły zadbać o zachowanie i zabezpieczenie materialnych dóbr swojej niemal osiemsetletniej historii i kultury. Podstawowym źródłem informacji na temat historii biblioteki przedstawionej w niniejszym artykule są materiały przechowywane w bibliotece klasztornej oraz Archiwum Benedyktynek w Staniątkach.

\section{Początki księgozbioru}

Już w XI wieku w benedyktyńskich klasztorach w Św. Krzyżu na Łysej Górze, w Tyńcu, Mogilnie, Lubniu Wielkopolskim i Sieciechowie działały skryptoria i biblioteki ${ }^{6}$. W staniąteckim klasztorze sióstr benedyktynek zalążkiem księgozbioru były rękopisy przepisywane na miejscu lub kupowane (m.in. od tynieckich benedyktynów), służące sprawowaniu liturgii (księgi liturgiczne, homiliarze, tek-

Nr 1422, nr top. 651. Dr Beata Wojewoda wyraziła pisemną zgodę na wykorzystanie swojej pracy magisterskiej na potrzeby niniejszej publikacji.

${ }^{3} \mathrm{~W}$ jednej z nowszych bibliografii piśmiennictwa na temat bibliotek kościelnych, spośród 192 pozycji odnoszących się do bibliotek klasztornych, tylko 13 prac dotyczy księgozbiorów zakonów żeńskich, w tym 5 odnosi się do księgozbiorów benedyktynek. Zob. M. Janiak, K. Bednarska-Ruszajowa, Archiwa i biblioteki kościelne w publikacjach polskich. Bibliografia, „Fides. Biuletyn Bibliotek Kościelnych", nr 1-2 (1997) s. 78-172. Te niekorzystne proporcje powtarzają się też w innych opracowaniach, zob. np.: B. Warząchowska, Biblioteki klasztorne na łamach „,Naszej Przeszłości”. Zarys problematyki, „Archiwa, Biblioteki i Muzea Kościelne” (dalej: ABMK), 96 (2011) s. 197-208.

${ }^{4}$ B. Krasnowolski, Historia klasztoru Benedyktynek w Staniątkach, Kraków 1999, s. 68, 160 , 302-310. W staniąteckim klasztorze już w drugiej połowie XVI wieku prowadzono szkołę dla panien świeckich traktując to jako obowiązek klasztoru podyktowany wymogami reguły. Istniał ścisły rozdział szkoły świeckiej i nowicjatu. W roku 1782 podjęto ideę utworzenia przy klasztorze szkoły rządowej. Jej działalność rozpoczęła się w listopadzie 1784 roku i obejmowała szkołę dla panien oraz szkołę dla dziewcząt wiejskich (przetrwała do roku 1855). W roku 1843 otwarto też szkołę dla chłopców. W latach 1861-1871 prowadzono tu kurs pedagogiczny, zaś w roku szkolnym 1910/1911 prywatny kurs z zakresu pierwszego roku seminarium nauczycielskiego.

${ }^{5}$ W 1782 r. cesarz austriacki Józef II Habsburg wydał dekret o kasacie zgromadzeń zakonnych, które nie prowadziły szkół, ani nie sprawowały opieki nad chorymi. Wieloletnie doświadczenie sióstr w prowadzeniu szkoły dla panien świeckich było podstawą do utworzenia szkoły rządowej, co w konsekwencji uratowało klasztor przed kasacją. Na mocy dekretu w zaborze austriackim utrzymały się klasztory benedyktynek w Staniątkach oraz klarysek w Starym Sączu i Krakowie.

${ }^{6}$ K. Maleczyńska, Książki i biblioteki w Polsce w okresie zaborów, Wrocław 1987, s. 33. 
sty Pisma Świętego) 7 . Niestety żaden z nich nie ocalał. Nie mniej jednak to właśnie liturgia ukształtowała kulturę czytelniczą w tym zgromadzeniu. W benedyktyńskiej duchowości w codzienny porządek dnia wpisane bowiem były rozmyślania polegające na powolnym wypowiadaniu (a właściwie czytaniu - lectio) tekstu biblijnego, a następnie rozważaniu przeczytanych treści (meditatio). Aby sprostać temu zadaniu siostry musiały posiadać umiejętność czytania. Często wynosiły ją $\mathrm{z}$ domu rodzinnego, jednak od XVI wieku przybyłym do klasztoru dziewczętom zapewniano naukę czytania, bowiem w nowicjacie siostry rozpoczynały już systematyczną lekturę tekstów liturgicznych.

Najstarszą książką zachowaną do czasów współczesnych, jest łaciński Psałterz wydany w Norymberdze pod koniec XV wieku, w drukarni Fridericusa Crewsnera (informacja umieszczona w kolofonie). Inkunabuł ten jest obecnie jedynym w Polsce egzemplarzem Psałterza wydanym w tej oficynie ${ }^{8}$.

W XVI wieku w zgromadzeniu pojawiły się pierwsze druki. W okresie rządów sprawowanych przez ksienię Annę Modlnicką (1508-1518) spłonęła część klasztoru wraz z archiwum ${ }^{9}$. Przepadły wówczas m.in. metryki zakonne, księgi chórowe i prawdopodobnie większość księgozbioru.

Koniec XVI wieku i następne stulecie nie były dla konwentu czasem spokoju. W okresie rządów ksieni Zofii Szreniawskiej (1591-1607) w klasztorze wybuchł kolejny wielki pożar, powodując olbrzymie straty materialne. W czasie „potopu” szwedzkiego (ksienią była wówczas Katarzyna Lubieniecka 1634-1677), Szwedzi dziewięciokrotnie splądrowali klasztor i wywieźli z niego najcenniejsze rzeczy, w tym księgozbiór. Siostry zmuszone do opuszczenia Staniątek, udały się najpierw do Barcic, a następnie do Starego Sącza ${ }^{10}$.

Znamienną cechą staniąteckiego klasztoru jest to, że na przestrzeni wieków, pomimo wielu przeciwności losu (pożary, powodzie, grabieże i zniszczenia wojenne) największą uwage przywiązywano tu do duchowości oraz rozwoju intelektualnego. Taka postawa sprzyjała gromadzeniu księgozbioru. Było to możliwe dzięki hojności ofiarodawców, a także dzięki staraniom samych sióstr. Staniąteckie benedyktynki wywodziły się na ogół z dobrze sytuowanych rodzin szlacheckich i wstępując do zakonu przywoziły ze sobą różnorodne dobra materialne. Wśród nich były i książki (przede wszystkim modlitewniki oraz zbiory pieśni), które zakonnice mogły przechowywać w swoich celach. W zgromadzeniu panował zwyczaj, że książki, z których już nie korzystano, oddawano do klasztornego $\operatorname{archiwum}^{11}$.

\footnotetext{
${ }^{7}$ Benedyktynki staniąteckie Biblioteka: http://www.benedyktynki.eu/index.php?ram=s\&id=28(dostęp 23. 09. 2014 r.).

${ }^{8} \mathrm{~W}$ piśmie z dnia 13 czerwca 1962 r. do s. Anzelmy Przybylskiej, ówczesnej bibliotekarki staniąteckiej, kierownik Zakładu Starych Druków i Ośrodka Opieki nad Dawną Książką Biblioteki Narodowej, prof. dr Alodia Gryczowa pisze: „W odpowiedzi na pismo z dn. 28.V. br. dziękujemy uprzejmie za podaną wiadomość o druku, którego dokładny opis pozwolił na ustalenie wydania. Okazuje się, że jest to jedyny w Polsce obecnie znany egzemplarz Psałterza, opisany w bibliografiach Haina i Copingera pod nr 13773".

9 J. Marecki, Ksienie klasztoru staniateckiego, „Krakowski Rocznik Archiwalny”, 6 (2000) s. 102.

${ }^{10}$ Tamże, s. 107.

${ }^{11}$ Wojewoda, Biblioteka, s. 32.
} 


\section{Powstanie biblioteki}

Za rządów ksień Katarzyny Małachowskiej (1729-1753) oraz Marianny Józefy Jordanówny (1753-1772), siostrzenicy ksieni Małachowskiej, sytuacja ekonomiczna klasztoru była ustabilizowana, co pozwoliło na realizację wielu przedsięwzięć. Zmieniono wówczas m.in. wystrój kościoła na wczesnobarokowy, odnowiono i wyremontowano pomieszczenia klasztorne, zbudowano: drewniane oficyny dla księży, murowaną kamienicę dla gości, browar. Założono też ogród typu włoskiego oraz wybrukowano ścieżki wokół klasztoru. Na szczególną uwagę zasługuje tu działalność ksieni Marianny J. Jordanówny, założycielki biblioteki klasztornej. Była to osoba o głębokiej duchowości i szerokich horyzontach intelektualnych. Sama dużo czytała i krzewiła zamiłowanie do czytania w zakonie. Jej rozległe zainteresowania oraz erudycję tak opisuje Anna Kiernicka w kronice klasztoru z roku 1790: „Zacząć z nią o Piśmie świętym, rzekłby kto, iż całą na pamięć umie Biblię. O żywotach świętych y pustelników, jakby się między nimi chowała, o woynach y bataliach dawnych jakby przy nich była, o domach y familiach, jakby herbarze wydawała" 12 .

Niewykluczone, że inspiracją do założenia biblioteki mogły być kontakty ksieni Jordanówny z Andrzejem Stanisławem Załuskim, biskupem krakowskim w latach 1746-1758, wybitnym mecenasem kultury, bibliofilem, czołowym przedstawicielem oświecenia katolickiego w Polsce oraz fundatorem założonej w roku 1747 (wraz z bratem Józefem Andrzejem) biblioteki publicznej w Warszawie, jednej z największych bibliotek świata $\mathrm{w}$ drugiej połowie XVIII wieku ${ }^{13}$.

Ustalenie dokładnej daty utworzenia biblioteki klasztornej sprawia pewne trudności. Dziewiętnastowieczna kronikarka klasztoru podaje, iż stało się to w roku 1754, w parę miesięcy po tym, jak ksienią obrana została wspomniana już Marianna Józefa Jordanówna ${ }^{14}$. Tymczasem współczesna ksieni Jordanównie kronikarka, Anna Kiernicka, jako datę powstania biblioteki wymienia rok 1762: „Wspomniało się wyży Bibliothekę tu dokładniey, że ią założyła Xsieni Jordanówna R.P. 1762 obróciwszy nato iedną celę, którą kazała wyreparować pułkami przyzwoitymi ozdobić, nie żałując expensy na zakupienie nowych y odnowienie starych xążek, które zakonnice, każda swoje chowając a przez to się szarzały. Wiele już y po tym xiąg przybywało z czego jest tylko ozdoba klasztoru, ale y pomoc wielka do duchowieństwa zakonnicom”"15. Data ta pojawia się również w pierwszym rejestrze książek z roku 1774. Ksieni Marianna Józefa Jordanówna przeznaczyła na bibliotekę jedną z cel, z widokiem na ogród i staw. Pomieszcze-

${ }^{12}$ ABS, sygn. 48, A. Kiernicka, Dzieje klasztorne Staniątek od fundacyi aż dotąd, w bibliotece przellożeńskiej złożone w ręce Nayprzewielebnieyszey w Bogu Imci Panny Heleny Scholastyki Ogrodzki [ej] Xsieni tego klasztoru, Bogu na większa chwatę. Staniatki, 1790, s. 134, rkps.

${ }^{13}$ Biblioteka Załuskich, w: Encyklopedia wiedzy o książce, red. A. Birkenmajer, Wrocław 1971, s. 204-205.

${ }^{14}$ Ksieni Jordanówna sprawowała rządy w okresie od 25 listopada 1753 r. do 28 marca 1772 r. $\mathrm{Z}$ jej inspiracji podjęte zostały przez konwent pierwsze próby zbadania własnej historii; jeszcze za jej życia swą pracę w klasztorze rozpoczęła Anna Kiernicka, autorka najstarszej zachowanej kroniki klasztoru. Marecki, Ksienie, s.111-113.

${ }^{15}$ Kiernicka, Dzieje, s. 140. 
nie służyło jedynie do przechowywania książek. Na półkach umieszczono cały ówczesny księgozbiór, a opiekę nad biblioteką ksieni Jordanówna powierzyła przeoryszy. Pierwszą bibliotekarką została prawdopodobnie s. Anna Kiernicka ${ }^{16}$.

\section{Rozwój biblioteki}

Księgozbiór biblioteki powiększał się systematycznie, jak już wcześniej wspomniano, przede wszystkim poprzez zakup książek oraz darowizny osób duchownych (spowiedników, rekolekcjonistów, kapelanów) i świeckich (gości i przyjaciół klasztoru, nauczycieli szkolnych). Pierwsze książki do nowo utworzonej biblioteki zakupiła ksieni Jordanówna. Według najstarszego rejestru z roku 1774 biblioteka liczyła ponad półtora tysiąca tytułów starych druków i cenniejszych rękopisów. Prawdopodobnie księgozbiór biblioteki był bogatszy, na co wskazują ślady po wyrwanych kartkach w rejestrze. Większość książek z tego księgozbioru zachowała się. Spośród darowizn godnym uwagi jest dar ks. Wawrzyńca Rąmpalskiego, wieloletniego spowiednika sióstr ofiarowany „na wiązanie” (na imieniny) ksieni Agnieszce Scholastyce Łojowskiej w roku 1776. Zachowany rejestr wymienia 145 tytułów, z czego 43 to polonica ${ }^{17}$.

Ze znaczniejszych zapisów warto wymienić także dar Józefa Szaniawskie$\mathrm{go}^{18}$. Ofiarował on swe książki bibliotece dwukrotnie, w czerwcu oraz w lipcu 1841 roku. Były to druki z pierwszej połowy XIX wieku w języku niemieckim (20 tomów) i polskim ( 8 tomów) ${ }^{19}$. Część księgozbioru stanowią niewielkie, liczące od jednej do kilku książek, dary osób odwiedzających klasztor. Oprócz książek oddawano do biblioteki medale, monety, a także różnego rodzaju drobne przedmioty jak ,gałązkę kwiateczków z ogrodów Getsemani, a drugą z grobu św. Piotra w Rzymie" 20 .

${ }^{16}$ Anna Kiernicka (ur. ok. 1736 r. - zmarła w 1807 r.), mistrzyni nowicjatu, od 1784 r. prefekta szkoły, oprócz spisywania kroniki klasztoru zajmowała się też przepisywaniem nut. M. Borkowska, Leksykon zakonnic polskich epoki przedrozbiorowej. T. 2 Polska Centralna i Poludniowa, Warszawa 2005, s. 419.

${ }^{17}$ ABS, Nr 1401, nr top. 776, Reiestr xiag danych na wiazanie Nayprzewielebnieyszey YeyMCi Pannie Agnieszce Scholastyce Łojowskiej Xieni Zgromadzenia naszego Staniateckiego przez W. IMCi Xiędza Wawrzyńca Rąmpalskiego Spowiednika, tegoż zgromadzenia Proboszcza Mikluszowskiego Roku 1776, rkps.

${ }^{18}$ Józef Kalasanty Szaniawski (1764-1843) filozof, prawnik, historyk, publicysta, działacz polityczny, bibliofil, członek Warszawskiego Towarzystwa Przyjaciół Nauk oraz Rady Stanu Królestwa Polskiego. Przez całe życie gromadził bibliotekę. Zarejestrowana część księgozbioru liczyła ponad 7000 woluminów, całość musiała być znacznie większa. Część swego księgozbioru przekazał krakowskim jezuitom, a około 3000 woluminów jezuitom lwowskim. M. Manteufflowa, Szaniawski Józef Kalasanty, w: Słownik pracowników książki polskiej, Warszawa-Łódź 1972, s. 869870; M. Deszczyńska, Szaniawski Józef Kalasanty, w: Polski Słownik Biograficzny, t. 47/1, z. 192, Warszawa-Kraków 2010, s. 1-9.

${ }^{19}$ R. Nir, Rękopisy liturgiczne biblioteki PP. Benedyktynek w Staniątkach, „Częstochowskie Studia Teologiczne", 4 (1976) s. 166.

${ }^{20}$ ABS, sygn. 60, Kronika Klasztoru Staniąteckiego z czasu przełożeństwa Najprzew. D.P. Ksieni Genowefy A. Lazowskiej 1882-1906. T. 3, Staniatki 1883-1906, s.195-204, rkps. 
W 1805 roku pomieszczenie biblioteki odmalowano, wstawiono nowe regały, a księgozbiór został przejrzany i uporządkowany. Z upływem czasu okazało się, że sala biblioteczna jest zbyt ciemna i wilgotna (okno wychodziło na staw), co doprowadziło do zniszczenia części zbiorów. W roku 1828 z polecenia przeoryszy Anny Wójcickiej odnowiono więc pomieszczenie biblioteki, zachowując dotychczasowy układ półek, a zbiory ponownie uporządkowano. Za rządów ksieni Zofii Heleny Ludgardy Baryszewskiej ${ }^{21}$, opiekująca się biblioteką s. Józefa Hildegarda Kornecka, uzyskawszy od niej odpowiednie fundusze i przez ,pośrednictwo różnych przychylnych osób” dopilnowała, aby niszczejące książki oprawiono. Wizytujący klasztor w sierpniu 1882 roku biskup Alojzy Pukalski tak ocenił stan biblioteki: „nie uszła też uwagi Naszej i biblioteka klasztorna. Lustrując zbiór książek tamże się znajdujących nabraliśmy tego przekonania, że nie tylko pilna, ale i umiejętna ręka Siostry Bibliotekarki pracuje nad tem, aby książki pożyteczne i pomocne tak przy ascetycznej, jako też szkolnej oraz literackiej, odpowiadały potrzebom (...) Sióstr. Przekonaliśmy się również, że taż Siostra Bibliotekarka spisuje kronikę klasztoru (...), za co jej słuszna i sprawiedliwa należy się pochwała nasza"22.

W roku 1883 na polecenie ksieni Wandy Genowefy Łazowskiej ${ }^{23}$ bibliotekę przeniesiono do nowej, obszerniejszej celi. Wybrano tym razem pomieszczenie jasne (okna wychodziły na wschód) i suche, co zapewniało zbiorom odpowiednie warunki przechowywania. Warto podkreślić, że ksieni Łazowska przywiązywała ogromną wagę zarówno do pogłębiania życia duchowego, jak i podnoszenia poziomu intelektualnego zgromadzenia. Wyrazem tego był stały rozwój zasobu biblioteki, powiększanej poprzez zakupy książek oraz prenumeratę czasopism. W 1886 roku podjęto prace nad ponownym skatalogowaniem zbiorów. Ówczesna bibliotekarka, s. Antonina Scholastyka Kaładulska, korzystając z fachowej pomocy o. Stanisława Załęskiego ${ }^{24}$ opracowała katalog systematyczny. Fakt ten odnotowany został w kronice klasztornej: ,,[biblioteka] ozdobiona jest uporządkowaniem katalogu i rejestrem - co zawdzięczać trzeba przez szczególnie związany stosunek z czcigodnymi Ojcami JJ [Jezuitami], mianowicie z szanownym ojcem Stanisławem Załęskim który wysokim wykształceniem, znajomością urządzeń biblioteki w kraju dopomógł światłą radą - połączyć praktyczność z zastosowaniem biblioteki Ich zakonu - lubo w skromnych rozmiarach"25. Według Katalogu Biblioteki W.W. PP. Benedyktynek w Staniątkach 1886 ówczesny księgozbiór liczył ponad 2460 książek. W XIX wieku zaznaczył się wyraźny podział

${ }^{21}$ Zofia Helena Ludgarda Baryszewska - ksieni klasztoru w latach 1865-1882. Marecki, Ksienie, s.117-118.

${ }^{22}$ Cyt. za: Krasnowolski, Historia, s. 317.

${ }^{23}$ Wanda Genowefa Abundacja de Łada Łazowska - ksieni klasztoru w latach 1882-1906. Marecki, Ksienie, s. 118.

${ }^{24}$ Stanisław Załęski (1843-1908), jezuita, kaznodzieja we Lwowie (1871-1881) oraz w Krakowie (1881-1893), współpracownik „Przeglądu Lwowskiego”, autor prac z historii jezuitów oraz kartuzów i bazylianów. Główne dzieło: Jezuici w Polsce, t. 1-5, 1900-1906. Załęski Stanisław, w: Wielka Encyklopedia PWN, Warszawa 2001-, T. 30, s. 219-220.

${ }^{25}$ Kronika, T. 3, s. 57. 
księgozbioru na część obejmującą najcenniejsze zbiory oraz część, którą siostry wykorzystywały na bieżąco. Pod koniec XIX wieku utworzono oddzielne stanowisko dla bibliotekarki. Pierwszą została s. Antonina Scholastyka Kaładulska ${ }^{26}$. Kontynuowano prace nad opracowaniem zbiorów, o czym świadczą zachowane do czasów współczesnych katalogi z roku 1900 oraz 1909. Ks. Roman $\mathrm{Nir}^{27}$, $\mathrm{w}$ artykule o rękopisach liturgicznych w bibliotece staniąteckiej szacuje, że w roku 1900 biblioteka posiadała około 10000 tomów ${ }^{28}$. Z informacji zawartej w kronice klasztornej wynika, że w roku 1906 klasztor prenumerował 22 tytuły czasopism polskich i zagranicznych ${ }^{29}$. Podczas I wojny światowej, w listopadzie 1914 roku, w wyniku ofensywy armii austriackiej i ośmiodniowego bombardowania klasztoru, w gruzach legła część zabudowań, zniszczono i zrabowano wiele cennych przedmiotów, w tym książek ${ }^{30}$. W okresie dwudziestolecia międzywojennego, za rządów ksieni Kazimiery Hilarii Szczerbianki ${ }^{31}$, prestiż staniąteckiego zgromadzenia wzrósł w skali całego kraju ${ }^{32}$. W 1923 roku otwarte zostało pięcioletnie gimnazjum ziemiańskie, co otworzyło przed konwentem nowe możliwości. W roku 1924 funkcję bibliotekarki objęła Zofia Celestyna Krzakowska. Rozpoczęto wówczas prace przygotowawcze, mające na celu całościowe skatalogowanie zbiorów. W okresie okupacji niemieckiej (1939-1945) życie sióstr toczyło się pozornie bez zmian, zgodnie z rytmem wyznaczonym przez wielowiekową benedyktyńską tradycję. Wiadomo jednak, że pomimo stacjonujących w budynku szkolnym wojsk niemieckich, w klasztorze gościły rzesze uciekinierów oraz prowadzono tajne nauczanie. Większość cennych przedmiotów siostry ukryły. Na polecenie ksieni Terlikiewiczówny ${ }^{33}$, s. Helena Anzelma Przybylska (późniejsza bibliotekarka) ukryła „,w schowku pod schodami przy kaplicy” pergaminowe księgi chórowe, przywileje królewskie oraz najcenniejsze ornaty i srebra liturgiczne ${ }^{34}$. Pomimo trwania działań wojennych rozpoczęto prace nad katalogowaniem zbiorów. Ich efektem był opracowany w latach 1940-1945 przez siostry: Helenę Stefanię Sufryd i Helenę Anzelmę Przybylską, katalog starodruków. Opisano w nim zaledwie 397 książek, po czym prace przerwano.

${ }^{26}$ Wojewoda, Biblioteka, s. 44.

${ }^{27}$ Ks. dr Roman Nir (ur. 1940), archiwista, bibliograf, historyk bibliotek, ekspert w zakresie opracowań inkunabułów, starodruków i rękopisów. Od 1978 r. aż do przejścia na emeryturę w roku 2009 pełnił funkcję dyrektora Archiwum Polonii w Orchard Lake (USA). http://www.videofact. com/nir.htm (dostęp: 23. 09. 2014).

${ }^{28} \mathrm{Nir}$, Rękopisy, s. 166.

${ }^{29}$ Wojewoda, Biblioteka, s. 45-46.

${ }^{30}$ Specyficzną ,pamiątką" po bombardowaniu są pociski artyleryjskie wbite w północny mur kościoła.

${ }^{31}$ Kazimiera Eugenia Maksyma Hilaria Szczerbianka - ksieni w latach 1907-1939. Marecki, Ksienie, s. 119.

${ }^{32}$ Ksieni Szczerbianka była wybitną osobowością, mającą niekwestionowaną pozycję wśród benedyktynek w całym kraju, czego dowodem był jej wybór na prezeskę nowo utworzonej unii klasztorów podczas kapituły generalnej w lutym 1933 roku.

${ }^{33}$ Irena Modesta Salezja Terlikiewicz - ksieni klasztoru w latach 1939-1963. Marecki, Ksienie, s. $119-120$.

${ }^{34}$ Krasnowolski, Historia, s. 409. 
Powojenne dzieje konwentu to przede wszystkim okres narastających represji politycznych, których przejawem była m.in. likwidacja szkoły. Apogeum represji nastąpiło w latach 1954-1956. W dniu 30 lipca 1954 roku decyzją władz państwowych przesiedlono siostry do Alwerni. Podczas pospiesznego pakowania pod nadzorem „kierownictwa akcji przesiedleńczej” zniszczeniu i rozproszeniu uległo wiele książek. Ksieni klasztoru w latach 1995-1998, Joanna Radwańska tak wspominała ten moment: ,nie nadążano pakować biblioteki, książki rzucano jak siano"35. Powrót sióstr do Staniątek stał się możliwy dopiero w wyniku tzw. odwilży popaździernikowej w 1956 roku. Mimo trudności z przeprowadzką, siostry bardzo dbały, aby cenne zbiory klasztoru, w tym zasoby biblioteczne, nie uległy zniszczeniu. Po powrocie księgozbiór biblioteki wymagał nowego rozmieszczenia i uporządkowania. Decyzję o rozpoczęciu prac nad organizacją biblioteki podjęła ksieni klasztoru Alina Imelda Niewmierzycka ${ }^{36}$. W efekcie oddzielono najcenniejsze zbiory, tj. rękopisy i starodruki. Przeniesiono je do małego pomieszczenia na pierwszym piętrze. Pozostały księgozbiór umieszczono w trzech salach na parterze. Lokalizacja księgozbioru od tego czasu pozostała niezmieniona. Opiekę nad biblioteką kontynuowała s. Helena Anzelma Przybylska - kronikarka życia zakonu, od lat zaangażowana w zabezpieczanie i opracowanie księgozbioru. Do niektórych rękopisów klasztornych oraz obrazów dołączyła własnoręczne adnotacje dotyczące pochodzenia, autorstwa i historii poszczególnych dzieł. W latach 1965-1984 s. Anzelma prowadziła księgę akcesyjną książek zakupionych lub darowanych ${ }^{37}$. Uporządkowała kolekcję starodruków rozmieszczając je na regałach według miejsca wydania. Podjęła próbę ich katalogowania, ale udało się jedynie opracować katalog starych druków oficyn wielkopolskich dla Biblioteki Kórnickiej. Po śmierci siostry Anzelmy Przybylskiej w 1990 roku opiekę nad biblioteką przejęła s. Janina Assumpta Lizoń, która do końca swego życia kontynuowała prace rozpoczęte przez poprzedniczkę. W latach 2010-2011 księgozbiorem zajmowała się s. Agata (nowicjuszka), a od 2011 roku biblioteką opiekuje się s. Małgorzata Borkowska.

\section{Biblioteka szkolna}

Z względu na długotrwałą tradycję oświatową staniąteckiego zgromadzenia, warto zwrócić uwagę na tzw. księgozbiór szkolny, który nie wchodził w skład biblioteki klasztornej. Siostry benedyktynki uważały, że prowadzenie szkół, to jeden z najważniejszych aspektów „zewnętrznej” aktywności klauzurowego klasztoru Jak już wcześniej wspomniano, prowadzenie działalności oświatowej uratowało klasztor przed likwidacją w roku 1782. Księgozbiór, składający się głównie z podręczników oraz literatury pięknej pełnił funkcję księgozbioru podręcznego, dlatego ,przechowywano go w klasach, w specjal-

35 Tamże, s. 429.

${ }^{36}$ Tamże, s. 432-433

${ }^{37}$ ABS Nr 1407, nr top. 645, Księga akcesyjna. Kupno nowych ksiażek $i$ darowizny dla biblioteki klasztoru S[ióstr] Benedyktynek w Staniątkach za przetożeństwa ksieni Aliny Imeldy Niewmierzyckiej. Staniątki 1965-1990, 382 s. 
nie do tego przeznaczonych szafach. W 1871 roku sporządzono Spis książek i przyborów naukowych $w$ wyższej szkole żeńskiej PP. Benedyktynek $w$ Staniątkach. Spis obejmuje kilkanaście działów tematycznych, odpowiadających nauczanym przedmiotom. W opisie książki uwzględniono takie elementy jak: numer pozycji w obrębie działu, tytuł dzieła, nazwisko autora, rok zakupu, liczba tomów. Wyróżniono następujące działy:
I. Religia
II. Polski język
A. Nauka czytania i dostrzegania (oglądów)
B. Gramatyka
C. Nauka stylu
D. Literatura polska
III. Język niemiecki
A. Książki do czytania i gramatyki
B. Wskazówki i wzory do stylu
C. Literatura niemiecka

Kolejnych 16 działów nie posiada już oznaczeń cyfrowo-literowych, dopisywano je stopniowo, prawdopodobnie w miarę pojawiania się nowych przedmiotów. Są wśród nich:

Historia polska - Książki, atlasy, mapy

Historia powszechna - Książki, atlasy, mapy

Geografia - Książki, atlasy, mapy

Rachunki - Książki, przyrządy

Historia naturalna - Książki, obrazy, modele, okazy

Książki do czytania dla uczennic

Fizyka - Książki i tablice

Kaligrafia

Rysunki

Roboty ręczne

Śpiew

Gospodarstwo domowe, kobiece i higiena

Język francuski

Muzyka

Pedagogika i dydaktyka

Czasopisma pedagogiczne i innej treści

W dwudziestoleciu międzywojennym wraz z powołaniem do życia pięcioletniego gimnazjum ziemiańskiego, staniątecka szkoła klasztorna osiągnęła szczyt swego rozwoju ${ }^{38}$. W gimnazjum funkcjonowały dwie biblioteki: dla nauczycieli oraz dla uczennic. W roku szkolnym 1924/1925 pierwsza z nich liczyła 1300 pozycji, druga ponad 8 000. Z okresu 1919-1925 pochodzi Spis książek i podręczni-

${ }^{38}$ W roku szkolnym 1923/1924 gimnazjum rozpoczęło działalność, a pod koniec 1926 roku szkoła otrzymała oficjalną nazwę: „Ziemiańskie Gimnazjum Żeńskie im. św. Scholastyki Panien Benedyktynek w Staniątkach”. Krasnowolski, Historia, s. 384. 
ków nauczycielskich - szafa na dormitarzu ${ }^{39}$ zawierający opisy ponad 500. Całość podzielona jest na dwadzieścia działów głównych:

1. - arcydzieła polskie i obcych pisarzy (z opracowaniami)

- dzieła bez opracowań. Biblioteka Powszechna Mrówki i inne

- charakterystyki literackie

- biblioteka krytyczna arcydzieł

- historia literatury i podręczniki

- studia literackie, rozprawy i szkice

- literatura powszechna - historia literatury

- wypisy polskie

2. Pedagogika, psychologia, dydaktyka, logika

3. Przewodniki praktyczne

4. Gramatyka

5. Pisownia, stylistyka

6. Historia polska, opisy, pamiętniki historyczne

7. Historia powszechna

8. Historia biblijna, kościelna

9. Geografia

10. Sztuki piękne

11. Historia naturalna

12. Fizyka i chemia

13. Somatologia, higiena, gospodarstwo, gimnastyka

14. Arytmetyka, algebra, geometria

15. Rysunki

16. Różne

17. Słowniki encyklopedyczne

18. Atlasy mapy

19. Książki poglądowe

20. Książki niemieckie i innych języków

Biblioteka szkolna przetrwała do roku 1953, kiedy to działalność staniąteckiego gimnazjum została przez ówczesne władze ostatecznie zakazana. Wysiedlonym w 1954 roku siostrom nie pozwolono zabrać ani wyposażenia gabinetów szkolnych, ani zbiorów szkolnej biblioteki. Majątek ten, poza częścią zbiorów biblioteki szkolnej, został wywieziony z klasztoru i rozdzielony wśród okolicznych szkół. Po powrocie z wygnania, w 1957 roku konwent czynił usilne starania o reaktywowanie szkoły, ale bezskuteczne. Ostatecznie w dawnym budynku szkolnym w roku 1959 utworzono Dom Rekolekcyjny.

\section{Rejestry i katalogi biblioteki klasztornej}

Staniąteckie katalogi biblioteczne stanowią niezwykle cenne źródło informacji dotyczącej jakościowego i ilościowego stanu księgozbioru. Pierwszy rejestr książek pochodzi z roku 1774. Prace nad nim rozpoczęły się prawdopodobnie już

\footnotetext{
${ }^{39}$ Spis książek i podręczników nauczycielskich. Staniątki 1919-1925, 100 s., rps.
} 
chwili utworzenia biblioteki, tj. w roku 1762 i trwały do roku 1774. Sporządzony został przez siostrę Annę Kiernicką i nosi nazwę: ,Rejestr ksiązek znayduiacych się w Bibliotece Klasztoru Staniateckiego zatożoney przez Nayprzewielebnieysza w Bogu JMC Pannę: Maryannę Józefę Jordanownę. Xięnią tego Klasztoru w R.P. 1762 Za przełożeństwa zaś Nayprzewielebnieyszej w Bogu IMCi Panny Agnieszki Scholastyki Łojowskiej Przez Przewielebna w Bogu IMC Pannę Helenę Ogrodzka Przeorysza z Rewidowany: od jednej siostry Tegosz Zgromadzenia Wiernie napisany Roku Pańskiego 1774 Dnia 1 Października"40. Do pierwotnej nazwy rejestru dopisano w późniejszym okresie uwagę: „Chędożona Biblioteka nasza R.P. 1805 przez jedną siostrę zakonną, w Roku 1828 za Przeorystwa Przewiel. w Bogu P. Anny Wójcicki - cała biblioteka malowana i chędożona ze wszystkim za jej staraniem".

W rejestrze osobno zapisano książki polskie oraz książki łacińskie, dzieląc je dodatkowo według formatów. Układ rejestru odzwierciedlał sposób ustawienia książek na półkach.

Jak widać na fotografii (fot. 3) opis książki zawierał: tytuł, nazwę autora (występuje po tytule lub jest pomijana), miejsce i rok wydania (nieliczne pozycje), liczbę egzemplarzy poszczególnych tomów oraz ogólną sumę jednostek. W późniejszych latach rejestr był kilkakrotnie uaktualniany. Świadczą o tym liczne skreślenia i zaklejenia poszczególnych pozycji, poprawki lub uzupełnienia (np. miejsca i daty wydania) sporządzone innym charakterem pisma oraz inną barwą atramentu. Prawdopodobnie związane to było z porządkowaniem biblioteki przeprowadzonej w roku 1805 i 1828. Do rejestru dołączony jest spis książek podarowanych ksieni Łojowskiej przez księdza Wawrzyńca Rąmpalskiego.

Efektem prac nad opracowaniem zbiorów w 1886 roku jest Katalog Biblioteki W.W. PP. Benedyktynek w Staniątkach $1886^{41}$. Jest to zeszyt z ozdobną stroną tytułową, w którym opisane zbiory podzielono na działy tematyczne. Każdy dział oznaczony został dodatkowo literami alfabetu:

Ascetyka AB

Żywoty Świętych i sławnych mężów CD

Teologia E

Kazania F

Historia Kościoła G

Medytacje $\mathrm{H}$

Literatura K (w zakres działu wchodziły książki o treści religijno-patriotycznej)

Pisma periodyczne L

Rękopisy M

W miarę powiększania się zbiorów dopisano ołówkiem kolejne działy:

Medale Obrazki Portrety Krajobrazy N

Ascetyka OP

Medytacje RS

Ascetyka T

${ }^{40}$ ABS Nr 1401, nr top. 776, Rejestr książek znajdujących się w Bibliotece Klasztoru Staniateckiego 1762, $42 \mathrm{~s}$.

${ }^{41}$ ABS Nr 1402, nr top. 159, Katalog Biblioteki P.P. Benedyktynek Staniatki rok 1886, $306 \mathrm{~s}$. 
W opisie dzieła uwzględniono następujące elementy: nazwisko, imię, godność (ksiądz lub nazwa zgromadzenia w skrócie, do którego należał autor), tytuł, rok i miejsce wydania, liczba tomów. Część książek opisanych w katalogu ponumerowano (najwyższy numer to 2460), późniejsze wpisy nie posiadają już numeracji. Działy katalogu odzwierciedlały ustawienie książek na półkach.

W staniąteckim archiwum klasztornym znajdują się ponadto dwa katalogi biblioteczne sporządzone na początku XX wieku. Pierwszy pochodzi z roku $1900^{42}$, drugi z roku 1909 (niekompletny) ${ }^{43}$. Opis książek w obydwu katalogach jest identyczny i zawiera: nazwę autora, w przypadku dzieła tłumaczonego nazwę tłumacza, tytuł, miejsce wydania, rok wydania, liczbę tomów oraz liczbę egzemplarzy. Katalogi obejmują czterdzieści działów tematycznych, według których ustawiono książki w bibliotece. Przytoczone poniżej nazwy poszczególnych działów doskonale charakteryzują profil zgromadzonego księgozbioru.

1. Życie Pana Jezusa

2. O naśladowaniu P. Jezusa

3. O Najświętszym Sakramencie

4. O Najświętszy Sercu P. Jezusa

5. O męce Pana Jezusa

6. Inne książki o Panu Bogu

7. Książki na miesiąc maj

8. O Najświętszej Pannie Maryi

9. Rozmyślania

10. Rekolekcje

11. O śmierci

12. O wieczności

13. Książki duchowne do czytania wiek XVII

14. Książki duchowne do czytania wiek XVIII

15. Książki duchowne do czytania wiek XIX

16. Książki duchowne do czytania wiek XX

17. Książki duchowne niemieckie

18. Książki duchowne francuskie

19. O świętym Józefie

20. Żywoty różnych świętych razem

21. Żywoty świętych mężów

22. Żywoty świętych niewiast

23. Teologia. Pismo Święte

24. Ewangelie

25. Psałterze

26. Ceremoniarze

27. Martyrologium

${ }^{42}$ ABS Nr 1403, nr top. 684, Spis książek biblioteki Klasztoru Panien Benedyktynek w Staniatkach 1900, $190 \mathrm{~s}$.

${ }^{43}$ ABS Nr 1404, nr top. 162, Spis książek biblioteki Klasztoru Panien Benedyktynek w Staniątkach 1909, ss. 392 [zapisanych 137]. 
28. Katechezy

29. Książki teologiczne do czytania

30. O zakonie benedyktyńskim

31. O innych zakonach

32. Literatura religijna

33. O ziemi świętej

34. O unitach

35. Miasto Kraków

36. Herbarze

37. O Żydach

38. Kazania

39. Literatura świecka

40. Czasopisma

Jak już wcześniej wspomniano, w okresie II wojny światowej siostry Helena Stefania Sufryd oraz Helena Anzelma Przybylska podjęły kolejną próbę opracowania staniąteckiego księgozbioru. Udało się skatalogować tylko niewielką część zbiorów - 397 starodruków. Opracowane starodruki zapisano w zeszycie pod nazwą Katalog starodruków pisany przez bibliotekarki P. Helenę Stefanię Sufryd i P. Helenę Anzelmę Przybylska w latach 1940-1945. Opis książki obejmował takie elementy jak: numer bieżący, sygnatura, data, tytuł dzieła, tom, numer wydania, wydawca, miejsce i rok wydania, cena, miejsce nabycia, uwagi. Katalog, oprócz roli informacyjnej miał pełnić równocześnie funkcję inwentarza bibliotecznego. Siostry bibliotekarki opracowały też nowy schemat podziału tematycznego zbiorów obejmujący zarówno księgozbiór klasztorny, jak i bibliotekę szkolną. Wyróżnione zostały działy główne oznaczone cyframi rzymskimi oraz poddziały oznaczone literami według następującego porządku:

I. Archiwum biblioteczne

II. Filozofia

III. Teologia

A. Pismo Święte

B. Literatura Pisma Świętego

C. Dogmaty

D. Apologetyka

E. Liturgika

IV. Asceza

A. Nabożeństwa

B. Rozmyślania

C. Czytania duchowe

D. Czytania o Sercu Pana Jezusa

E. Czytania o Matce Bożej

F. Mowy i kazania

V. Monografie

A. Biografie 
B. Monografie miejscowości

VI. Historia Kościoła

A. Historia Kościoła w ogóle

B. Historia Kościoła w Polsce

C. Zakony

D. Zakony benedyktyńskie

E. Stowarzyszenia i bractwa

F. Sprawy misyjne

VII. Historia i wychowanie

A. Historia w ścisłym znaczeniu

B. Heraldyka

C. Historia literatury

D. Zagadnienia społeczne

E. Przyroda

VIII.Sztuka

A. Poezja

B. Muzyka i śpiew

C. Malarstwo

IX. Czasopisma

X. Słowniki i encyklopedie

XI. Rękopisy

Pomimo ambitnych planów nigdy nie dokończono prac nad nowym katalogiem.

\section{Najciekawsze kolekcje biblioteki klasztornej}

Do najstarszej części zbiorów należy wspomniany już łaciński Psałterz wydany w Norymberdze pod koniec XV wieku, w drukarni Fridericusa Crewsnera. Inkunabuł liczy 161 kart. Tekst ozdabiają ręcznie malowane inicjały w kolorze zielonym, żółtym, złotym i ciemnoniebieskim. Na jednej z kart (karty nie są numerowane), obok inicjału „L” widnieje nazwisko właścicielki „Anna Barbara Elżbieta Tabasowska słuska nigodna pana jezusowa i naświetsey panny maryi dobrodzieiki moi".

Pokaźną część zbiorów biblioteki stanowią starodruki. Jest ich w sumie 2327 , z czego 256 pozycji to siedemnastowieczne książki w języku polskim. Do najstarszych starodruków należy pochodzący z roku 1549, z drukarni Andrzeja Piotrkowczyka Psałterz Dawidów teraz znowu z łacińskiego, z greckiego i z rodowitego na Polski jest z pilnościa przełożony y z Argumentami y annotacjami dojaśniony przez O. Jakuba Wujka (trzecie wydanie przekładu) oraz Żołtarz Dawidów w tłumaczeniu na język polski Walentego Wróbla, wydany w drukarni Mikołaja Szarfenbergera w Krakowie w roku 1567.

Niektóre starodruki zachowały się w wielu egzemplarzach, co wskazuje, że siostry wspólnie odbywały medytacje nad tym samym tekstem. W siedemdziesięciu egzemplarzach zachowało się np. dzieło Tomasza à Kempis $O$ naślado- 
waniu Chrystusa. Najstarszy z nich pochodzi z roku 1570. Mieczysław Bednorz w artykule Jezuici a religijność polska sugeruje, że jest to egzemplarz wydania nie notowanego przez bibliografię Estreichera w edycji przekładów Jakuba Wujka ${ }^{44}$. Istotną część zbioru starodruków stanowią książki dotyczące życia zakonnego, np. Fortka niebieska albo raczej Czwiczenia Duchowne jednei stugi Bożej przykładem którei tak osoby zakonne iako y nabożne Bogu oddane moga się ćwiczyć chcac się poddać dusz swych oblubieńcowi z 1599 roku czy zachowana w sześciu egzemplarzach $O \dot{z} y w o c i e ~ z a k o n n y m$, iako ma być świątobliwie prowadzon, albo o każdodziennym w cnotach ćwiczeniu/ książka przez X Iakuba Alwareza SJ złożona, a na język polski przez X Szymona Wysockiego tegoż zakonu przełożona z roku 1628. Spośród starodruków najliczniejszą grupę stanowią różnego rodzaju rozmyślania. W klasztornej bibliotece zachowało się m.in. osiem egzemplarzy wydanej w Krakowie w 1614 roku książki Monstrancja Nowa albo Ćwiczenia Duchowe y Rozmyślania wielce nabożne o najświętszym Sakramencie od X. Łukasza Pinella złożone przez X. Szymona Wysockiego na polski przełożone, dwa egzemplarze z 1615 roku zatytułowane Morze Czerwone, albo Męki Zbawiciela naszego Jezusa Chrystusa nabożne opisanie, jedenaście pełnych oraz osiem częściowych egzemplarzy wydanych w roku 1629 Rozmyślań o tajemnicach wiary naszej, żywocie y męce Jezusowey [...] na sześć części podzielonych przez Ludwika Pontana [...] w thumaczeniu Jana Węgrzynkowica.

Biblioteka posiada także zbiór siedemnastowiecznych drukowanych modlitewników. Jest wśród nich Ray duszny wydany w 1604 roku (trzy egzemplarze), Nowy Ray duszny to jest rozmyślania nabożne na wszystkie niedziele i święta uroczyste [...] Z rozmaitych autorów zebrane przez X Szymona Wysockiego z roku 1608 (dziesięć egzemplarzy) czy wydany w Krakowie specjalnie dla kobiet Ray panieński z 1682 roku (osiem egzemplarzy). Warto dodać, że modlitewniki z reguły podpisane są nazwiskami właścicielek, często umieszczano w nich pod tekstem drukowanym odręczne zapisy innych modlitw.

Na szczególną uwagę zasługuje zbiór rękopisów liturgicznych. Kolekcja obejmuje antyfonarze, brewiarze, graduały, kancjonały, modlitewniki, mszały, medytacje oraz rozważania pisane w języku polskim lub łacińskim. Niektóre rękopisy są bogato iluminowane (np. miniatury wykonane są w złocie) oraz posiadają piękne różnokolorowe inicjały. Bogate są również ich oprawy wykonane ze skóry cielęcej z ornamentyką linearną i roślinną. Widnieją w nich także wyciśnięte złotymi literami nazwiska i imiona właścicieli. Rękopisami liturgicznymi zajmował się w latach 70. XX wieku ks. Roman Nir wydając ich drukowany katalog Rękopisy liturgiczne Biblioteki PP. Benedyktynek $w$ Staniątkach ${ }^{45}$. Katalog opisuje 31 w porządku chronologicznym. Do najstarszych należą Księga zwana Wielkanocna z roku 1535, Antyfonarz. Księga zwana Postna oraz Ksiega Adwentowa obie z roku 1536. Księgi napisane zostały przez tynieckich benedyktynów na zamówienie ksieni Doroty Szreniawskiej.

\footnotetext{
${ }^{44}$ M. Bednorz, Jezuici a religijność polska, „Nasza Przeszłość”, 20 (1964) s. 144-244.

${ }^{45}$ Nir, Rękopisy, s. 165- 183.
} 
Do najcenniejszych zbiorów rękopiśmiennych należą jednak kancjonały powstałe między rokiem 1586 a 1837 . Wśród nich znajdują się kancjonały tworzone przez same siostry, bowiem kultura muzyczna w staniąteckim konwencie stała zawsze na wysokim poziomie. Autorkami kancjonałów były m.in. siostry Zofia Orszula Stradomska, Elżbieta Latosińska, Scholastyka Ogrodzka, Zofia Borowińska (antyfonarze i graduały), Magdalena Kostecka (kancjonały i antyfonarze). Najstarszym zachowanym kancjonałem jest przepisany przez siostrę Katarzynę Stradomską Cancional pyosnek rozmaitych a nabożnych pisany roku pańskiego 1586 zawierający pieśni maryjne oraz pieśni poświęcone Bożemu Narodzeniu. Trzy kolejne kancjonały pochodzą z XVII w., pozostałe - XVIII i XIX wieku. Kancjonały zawierają 490 pieśni (369 w języku polskim i $121 \mathrm{w}$ języku łacińskim) łącznie z pastorałkami, kołysankami, powinszowaniami kolędowymi. Szczegółowy opis kancjonałów przedstawia opracowany przez ks. Wendelina Świerczka ${ }^{46}$ Katalog kancjonatów staniąteckich i pieśni $i^{47}$. Zdaniem ks. Romana Nira, cztery najstarsze kancjonały to prawdopodobnie pozostałość po większym zbiorze, który uległ zniszczeniu ${ }^{48}$.

Interesujący materiał do badań zakonnej duchowości stanowi zbiór około 70 egzemplarzy rękopiśmiennych medytacji. Siostry osobiście przepisywały, przerabiały lub tworzyły ich teksty. Rękopisy z reguły przechodziły z rąk do rąk i były wielokrotnie uzupełniane. Niektóre z nich mają specyficzną kompozycję graficzną, przypominającą drukowane modlitewniki np. pochodzący z końca XVII wieku rękopis modlitw, rozważań rekolekcyjnych oraz medytacji zatytułowany Serce strzałami mitości Bożej zranione i przez ognisk akty Bogu ofiarowane.

Jak widać książki zgromadzone w klasztornej bibliotece służyły przede wszystkim modlitwie, kontemplacji, pogłębianiu duchowości oraz rozwijaniu wiedzy religijnej. $Z$ pewnością jednak już poprzez sam fakt obcowania ze słowem pisanym, siostry miały możliwość rozwijania swojej osobowości i intelektualnego wzbogacania się.

\section{Obecna dzialalność biblioteki}

Biblioteka wraz z archiwum znajduje się w obrębie części klasztoru objętego klauzurą i zajmuje cztery pomieszczenia - trzy na parterze i jedno na pierwszym piętrze. Jedno z pomieszczeń na parterze przeznaczone jest na archiwum. W dwóch pozostałych przechowywany jest księgozbiór: w pierwszej sali druki z XIX i XX wieku (zbiór główny), natomiast w drugiej - pozostałość księgozbioru dawnej biblioteki szkolnej, zawierający przede wszystkim pozycje z literatury pięknej (lektury szkolne), książki obcojęzyczne (w języku niemieckim i francuskim) oraz roczniki prenumerowanych w przeszłości czasopism. W niewielkiej sali zwanej Anzelmianum (od imienia siostry Anzelmy Przybylskiej) ${ }^{49}$, zlokali-

${ }^{46}$ Ks. Wendelin Świerczek (1888-1974), muzykolog, badacz polskiej pieśni kościelnej. http:// bc.upjp2.edu.pl/dlibra/docmetadata?id=241\&from=pubindex\&dirids=1\&lp=650 (dostęp: 23.09 .2014 r.)

${ }^{47}$ W. Świerczek, Katalog kancjonałów staniąteckich i pieśni, ABMK, 41 (1980) s.127-189.

${ }^{48}$ Nir, Rekopisy, s. 167.

${ }^{49}$ Wojewoda, Biblioteka, s. 56. 
zowanej na pierwszym piętrze, znajduje się najcenniejsza część zbiorów, czyli rękopisy i starodruki. We wszystkich pomieszczeniach księgozbiór ułożony jest działowo, a w obrębie działów książki ustawiono chronologicznie według daty lub miejsca wydania. Osobno umieszczono biblie i wydawnictwa zagraniczne. Taka struktura i układ księgozbioru nie zmienił się od lat. Zbiory we wszystkich salach rozmieszczone są na dwustronnych metalowych regałach, natomiast rękopisy liturgiczne przechowuje się w oszklonych drewnianych szafach. Pomieszczenia wyposażone są też w stare meble, biurka, szafy, komody z szufladami.

Ze względu na brak kompletnej ewidencji (księgi inwentarzowe, katalogi) niemożliwe jest ustalenie danych dotyczących liczebności księgozbioru. Szacuje się, iż aktualnie w bibliotece znajduje się kilkanaście tysięcy woluminów, wśród nich około 500 rękopisów i ponad 2000 starych druków ${ }^{50}$. Z kolei w publikacji poświęconej rękopisom liturgicznym z 1976 roku ks. Roman Nir ocenił liczebność księgozbioru na około 15000 tomów, w tym 5000 starych druków, 500 rękopisów i 100 tytułów czasopism ${ }^{51}$. Zwraca uwagę trudna do wyjaśnienia rozbieżność liczb, w szczególności, gdy chodzi o starodruki. Być może sprzeczność ta wynika z odmiennych kryteriów przyjętych przy zaliczaniu wydawnictw do tej kategorii, gdyż nieznane są fakty, poświadczające tak radykalne zmniejszenie się księgozbioru w omawianym okresie.

Oprócz księgozbioru historycznego, w klasztorze znajduje się księgozbiór podręczny (kilkaset książek) przeznaczony do bieżącego wykorzystania przez siostry. Znajduje się on w pomieszczeniu przylegającym do sali rekreacyjnej. Zbiór jest opracowany w formie katalogu kartkowego. Tematyka księgozbioru jest różnorodna: książki teologiczne, homilie, medytacje, literatura beletrystyczna. Siostry same dobierają sobie lekturę i zabierają książki do swoich cel. Nie prowadzi się ewidencji tych wypożyczeń.

Od czterech lat biblioteką i archiwum klasztornym opiekuje się s. Małgorzata Anna Borkowska, łącząc ten obowiązek z działalnością pisarską i naukową. S. Małgorzata jest badaczką historii życia zakonnego, autorką setek publikacji, w tym kilkudziesięciu książek. Jej dorobek obejmuje m.in. opracowania dotyczące monastycyzmu i kultury religijnej w Polsce, tłumaczenia pism monastycznych greckich i łacińskich, książki dla dzieci i z zakresu literatury fantastycznej, artykuły opublikowane w miesięcznikach „Znak” i „Więź”. Jest doktorem honoris causa Katolickiego Uniwersytetu Lubelskiego Jana Pawła II ${ }^{52}$.

W chwili obecnej księgozbiór powiększa się głównie poprzez dary i zapisy testamentalne od osób zaprzyjaźnionych z siostrami zakonnymi oraz zakup. Nie istnieje stały budżet na zakup nowych wydawnictw. Książki nabywa się okazjonalnie w miarę potrzeb i możliwości finansowych. Zakupu dokonuje siostra opiekująca się biblioteką oraz ksieni zakonu. Nie ma również stałej prenumeraty czasopism, są one kupowane na bieżąco z kasy klasztoru. Trudna sytuacja finansowa zgromadzenia uniemożliwia bieżącą konserwację zbiorów, jak również ich kompleksowe

${ }^{50}$ Według informacji przekazanej przez s. Małgorzatę Borkowską.

${ }^{51}$ Nir, Rękopisy, s. 167.

${ }^{52}$ A. Strzępka, Niedościgniona rehabilitantka przeszłości, „Niedziela. Tygodnik Katolicki”, 25 (2011) s. 23. 
zabezpieczenie przed zniszczeniem. Klasztor posiada jedynie system ostrzegania przeciwpożarowego oraz w salach na parterze urządzenia zapewniające stałą temperaturę i wilgotność. Zbiory udostępniane są osobom zainteresowanym bez ograniczeń wyłącznie na miejscu za zezwoleniem ksieni klasztoru. Biblioteka nie posiada kserografu, zezwala się jedynie na fotografowanie dokumentów aparatem cyfrowym bez użycia flesza.

Jak wcześniej wspominano, kilkakrotne próby skatalogowania księgozbioru nie doprowadziły do opracowania pełnej informacji o zbiorach. W efekcie, do tej pory biblioteka nie posiada kompletnego katalogu. Aktualnie mimo ogromnych trudności finansowych, z jakimi boryka się zgromadzenie, przy dużym wsparciu ludzi dobrej woli, wolontariuszy, którym nie jest obojętny los klasztoru, ale też i jego cennego księgozbioru, Opactwu udało się pozyskać środki finansowe z Ministerstwa Kultury i Dziedzictwa Narodowego w ramach programu Dziedzictwo kulturowe. Ochrona i cyfryzacja dziedzictwa kulturowego ${ }^{53}$. W wyniku realizacji projektu, w 2013 roku zdigitalizowano i opracowano część zbioru rękopiśmiennych muzykaliów biblioteki. Digitalizację przeprowadzono w większości przypadków w formie reprodukcji fotograficznej w plikach RAW z zachowaniem wszystkich wytycznych Katalogu Dobrych Praktyk. Część mniejszych niż format A4 pozycji zostało zeskanowanych, ale ze względu na niestabilną pracę skanera w warunkach dużej wilgotności panującej w klasztorze zaniechano tej metody. Do celów publikacji na stronie internetowej pliki zostały poddane obróbce i zapisane w formacie jpg o zmniejszonej rozdzielczości, odpowiedniej do transmisji danych on-line. Utworzono platformę cyfrową udostępniającą zbiory wraz z partyturami. Ze zbiorów tych można korzystać bezpłatnie poprzez Cyfrową Bibliotekę Opactwa Św. Wojciecha Mniszek Benedyktynek w Staniątkach dostępną na stronie internetowej ${ }^{54}$ lub poprzez stronę domową klasztoru ${ }^{55}$. Zdigitalizowany zbiór to kolekcja kancjonałów staniąteckich oraz bezcenne manuskrypty zawierające śpiewy liturgiczne - graduały i antyfonarze. Aktualnie, dzięki Bibliotece Cyfrowej, można zdalnie dotrzeć do 168 publikacji. Strona internetowa umożliwia przeglądanie skatalogowanych w bazie danych treści oraz wyszukiwanie według zadanych kryteriów (np. tytułu, rodzaju dokumentu, roku powstania, fragmentu melodii). Umożliwia obejrzenie skanów i partytur pieśni ze zbioru kancjonałów opracowanych przez muzykologów. Do wybranych utworów dołączono transkrypcje z uwspółcześnioną pisownią i pliki dźwiękowe, które pozwalają na

${ }^{53} \mathrm{~W} 2013$ r., po pozytywnym rozpatrzeniu wniosku (nr 07403/13), MKiDN przyznało Opactwu dotację w wysokości 65500 zł na realizację zadania: „Dygitalizacja rękopiśmiennych muzykaliów biblioteki Opactwa Św. Wojciecha Mniszek Benedyktynek w Staniątkach wraz z ich opracowaniem muzykologicznym oraz utworzeniem platformy udostępniającej on line te zbiory wraz z partyturami”.

http://www.mkidn.gov.pl/pages/strona-glowna/finanse/programy-ministra/programy-z-lat -ubieglych/programy-mkidn-2013/dziedzictwo-kulturowe/ochrona-i-cyfryzacja-dziedzictwa-kulturowe.php (dostęp: 23. 09. 2014 r.).

${ }^{54}$ Cyfrowa biblioteka Opactwa Św. Wojciecha Mniszek Benedyktynek w Staniątkach: http:// biblioteka.benedyktynki.eu (dostęp 23.09.2014 r.)

${ }^{55}$ Benedyktynki staniąteckie: http://biblioteka.benedyktynki.eu (dostęp: 23. 09. 2014 r.) 
wysłuchanie danego utworu. Układ funkcjonalny platformy wzorowany jest na Europejskiej Bibliotece Cyfrowej Manuskryptów ${ }^{56}$. W przyszłości planowane jest tłumaczenie platformy na język angielski i niemiecki. Realizacja projektu umożliwiła upowszechnienie i promocję mało znanej kolekcji bezcennych muzykaliów należących do opactwa benedyktynek w Staniątkach. Utrwalenie zbioru w wersji cyfrowej zapewnia przetrwanie dokumentów w razie zniszczenia oryginałów $\mathrm{w}$ wyniku nieprzewidzianych zdarzeń. $\mathrm{W}$ ramach projektu zakupiono stanowisko komputerowe do katalogowania zbiorów oraz przechowywania danych, monitor, interfejs bazy danych, program do obróbki graficznej, dwa dyski przenośne. Będzie ono również pomocne przy opracowaniu katalogu rękopisów, a w przyszłości do prac nad katalogiem pozostałych zbioró $w^{57}$. Aktualnie ksieni klasztoru stara się o możliwość skatalogowania starodruków przechowywanych w bibliotece. Opracowanie zbiorów od strony merytorycznej zostanie powierzone zespołowi osób $\mathrm{z}$ dużym doświadczeniem badawczym w tym zakresie. Będzie również kontynuowana digitalizacja części rękopisów archiwalnych.

Uruchomienie strony internetowej klasztoru przyczyniło się do promocji biblioteki. Stronę na bieżąco aktualizuje artystka-fotografik Magdalena Poprawska, bezgranicznie zaangażowana $\mathrm{w}$ promocję klasztoru i jego cennych zbiorów. Popularyzacji biblioteki sprzyjają też pośrednio książki siostry Małgorzaty Borkowskiej oraz jej publikacje - felietony i artykuły - w prasie lokalnej, m.in. w „Gazecie Niepołomickiej”. Do działań promocyjnych należy zaliczyć także informowanie lokalnych mediów (prasa, radio, telewizja) o realizacji projektu digitalizacji rękopiśmiennych muzykaliów oraz portali, w tym Urzędu Miasta i Gminy w Niepołomicach, Starostwa Powiatowego w Wieliczce, Opactwa Benedyktynów w Tyńcu, Benedyktyńskiego Instytutu Kultury „Chronić dobro” oraz Wydawnictwa Benedyktynów. Należy mieć nadzieję, że już wkrótce kolejne informacje o postępie prac związanych z opracowaniem księgozbioru staniąteckiej biblioteki dotrą do wszystkich zainteresowanych tym zagadnieniem.

\section{Zakończenie}

Przyglądając się historii oraz oceniając stan obecny biblioteki zgromadzenia benedyktynek w Staniątkach należy stwierdzić, iż pomimo różnych przeciwności dziejowych cenny księgozbiór, przez wieki gromadzony i przechowywany w klasztorze, dotrwał do naszych czasów w dobrym stanie. Zawdzięczać to należy opiece ksień klasztoru i pieczołowitej trosce sióstr archiwistek i bibliotekarek. Zasoby biblioteki klasztornej stanowią nie tylko interesujący materiał źródłowy do badań nad historią Kościoła, w szczególności monastycyzmu i polskiej muzyki sakralnej na przestrzeni wieków, ale są również obiektem wielokierunkowych badań, w tym bibliotekoznawczych. Podjęte w ostatnim czasie inicjatywy zmie-

${ }^{56}$ Manuscriptorium. Europejska biblioteka cyfrowa manuskryptów. http://www.manuscriptorium.com (dostęp: 29. 09. 2014 r.).

${ }^{57}$ Informacje oparte na niepublikowanym raporcie końcowym z wykonania zadania w ramach programu Dziedzictwo kulturowe. Ochrona i cyfryzacja dziedzictwa kulturowego z roku 2013, autoryzowane przez Magdalenę Poprawską. 
rzające do kompletnego zewidencjonowania i digitalizacji zbiorów oraz zdalnego udostępnienia najcenniejszych obiektów, powinny się przyczynić do ich upowszechnienia, a tym samym do rozszerzenia prac badawczych.

Napawa optymizmem fakt, że wobec trudnej sytuacji finansowej i ,niedoborów kadrowych" konwent może liczyć na życzliwą pomoc i wsparcie ludzi dobrej woli, którzy nie szczędząc sił i czasu wspomagają działania na rzecz przybliżania zainteresowanym - również badaczom - dóbr kultury i źródeł wiedzy zgromadzonych w klasztornej bibliotece. Mimo, iż do finalizacji prac potrzeba jeszcze dużego nakładu pracy i sporych środków finansowych, można żywić nadzieję, że przy wsparciu instytucji państwowych i samorządowych oraz zaangażowaniu specjalistów z różnych dziedzin nauki i kultury, zadanie to zostanie doprowadzone do pomyślnego końca i zbiory staniąteckiej biblioteki będą służyły kolejnym pokoleniom badaczy.

Słowa kluczowe: biblioteka klasztorna, opactwo benedyktynek w Staniątkach

\title{
THE LIBRARY OF ST. ADALBERT'S ABBEY OF BENEDICTINE NUNS IN STANIĄTKI
}

\begin{abstract}
Summary
The article is devoted to the history and present state of the library of The Abbey of Benedictine Nuns in Staniątki, one of the oldest monasteries in Poland. Development of the library throughout centuries has been outlined an the contents of the book collection have been described. Special attention has been paid to the musical collections originating from XVI-XVIII cc., which currenty can be accessed by the digital library. The study is an attempt to present the isssue from a librarian's point of view. The problems discussed in the article reflect difficulties and challenges that have to be faced by numerous Polish monastery libraries.
\end{abstract}

Key words: monastery library, Abbey of Benedictine Nuns in Staniątki 


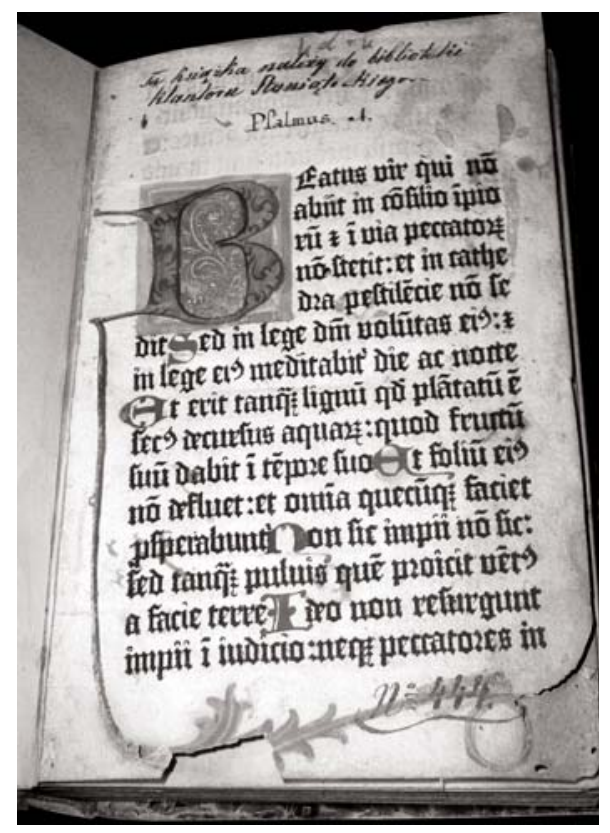

Fot. 1. Najstarsza książka w bibliotece staniąteckiej Psałterz z końca XV w. Fot. B. Janczak/ The oldest book in the library of Staniątki - Psalter of the late 15th century. Photograph: B. Janczak

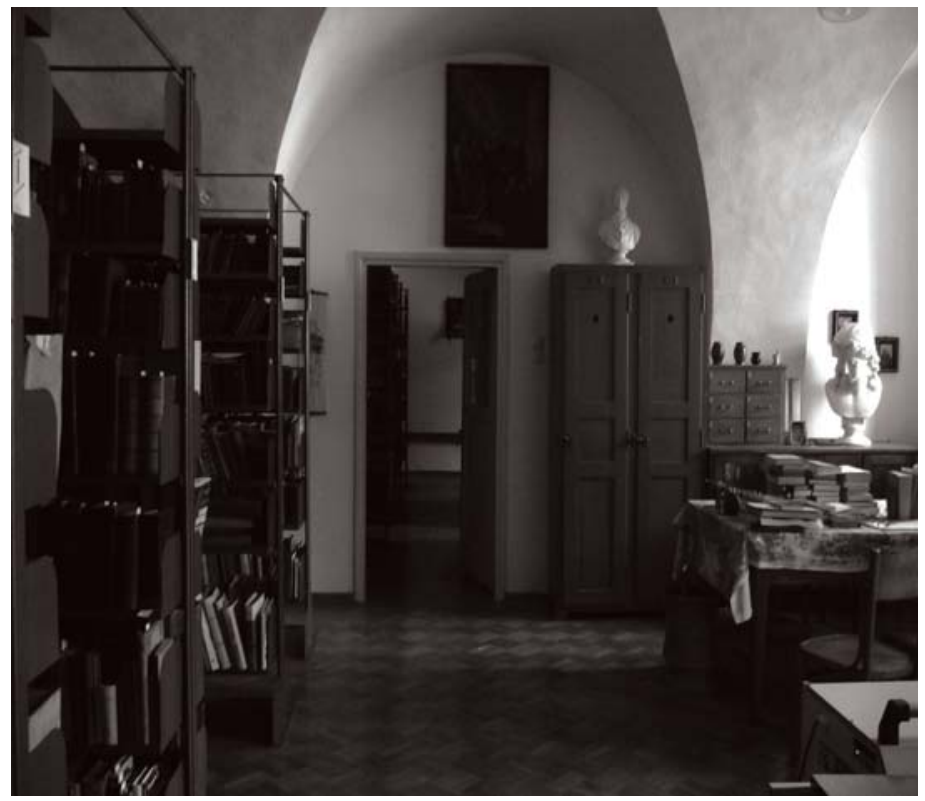

Fot. 2. Fragment biblioteki na parterze - druki XIX i XX-wieczne, w głębi księgozbiór szkolny. Fot. B. Janczak/ The fragment of the library on the ground floor - prints of the 19th and 20th centuries, in the background-the school book collection. Photograph: B. Janczak 


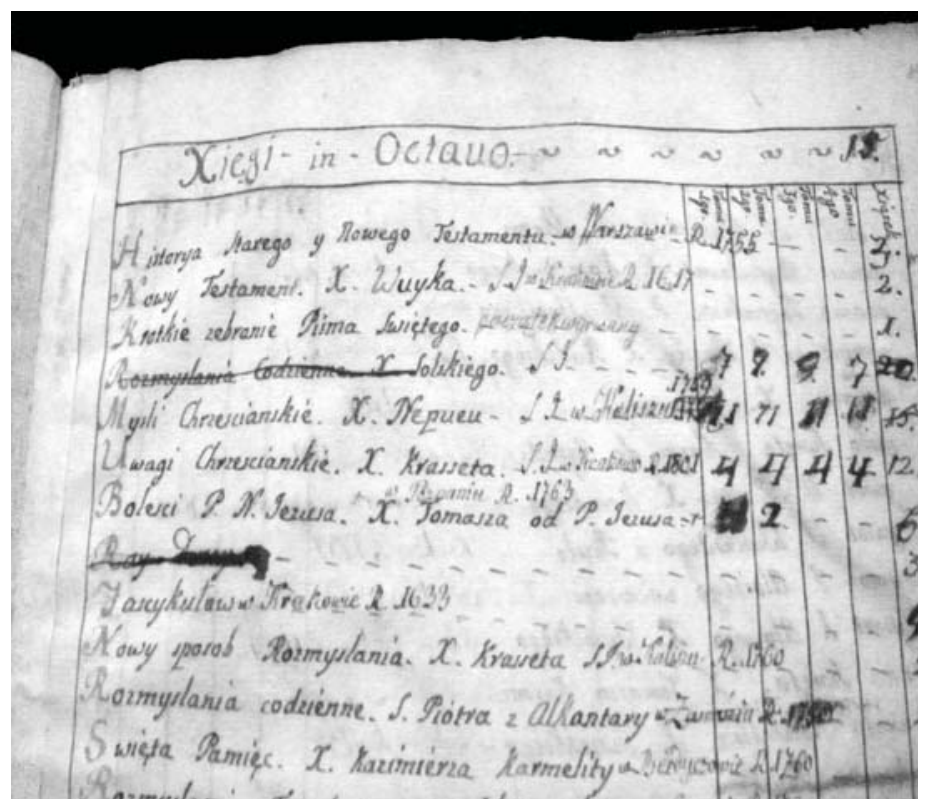

Fot. 3. Rejestr książek roku 1774. Xięgi [polskie] - in - Octavo. Fot. M. Dudziak-Kowalska/ The register of books of 1774. Books [Polish] - in - Octavo. Photograph: M. Dudzial-Kowalska

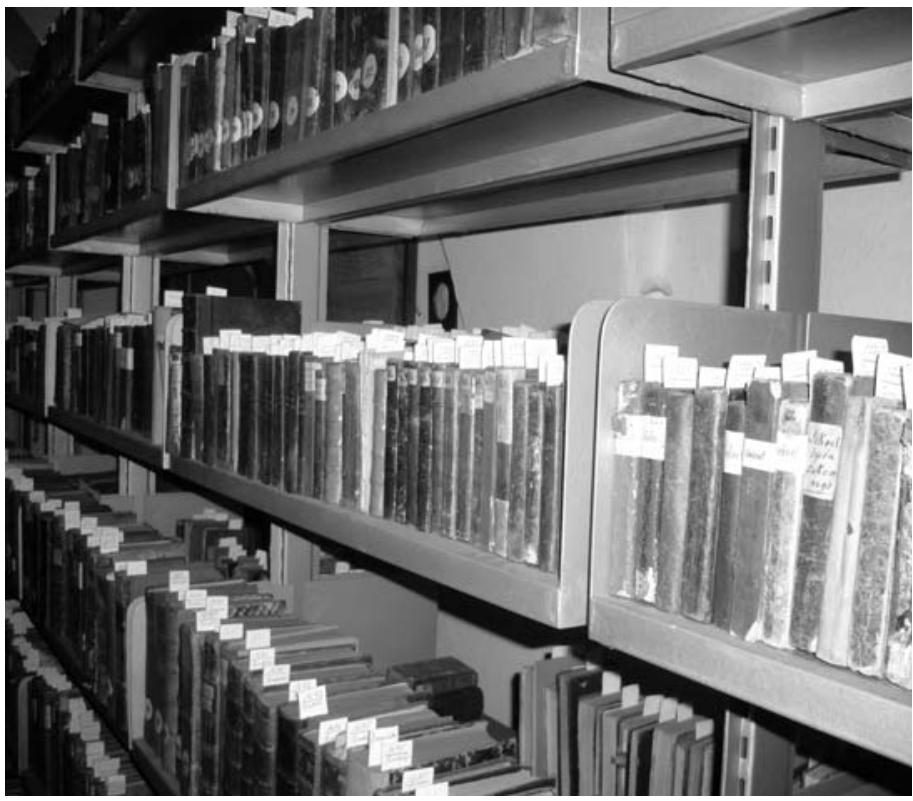

Fot. 4. Fragment biblioteki na pierwszym piętrze - kolekcja starodruków. Fot. B. Janczak/ The fragment of the library on the first floor - the collection of antique books. Photograph: B. Janczak 